\title{
The State of daymares and insomnias- Exploring the trepidation and Viciousness of Emergency in Rohinton Mistry's A Fine Balance
}

\author{
Dr R Latha Devi* \\ Assistant professor of English, University College of Engineering Nagercoil \\ (Anna University Constituent College) \\ Tamil Nadu, India \\ Email: lathadevigiri@gmail.com \\ Dr S Prabahar \\ Professor, Dept. of English, MS University, Tirunelvi, Tamilnadu \\ Email: prabhamsu@gmail.com
}

\begin{abstract}
:
This paper intends to portray the problems that the ordinary people encountered during Internal Emergency that is represented in Rohinton Mistry's novel A Fine Balance. The Internal Emergency proclaimed during the regime of Indira Gandhi, the then Prime Minister of India forms the backdrop for Mistry's novel A Fine Balance. . A Fine Balance, traces the social, political and historical development of India between the year of 1975 and 1985 and it portrays the horror and cruelty that was experienced by the people during the period. It entwines the story of four people who directly or indirectly become the victims of the Emergency. The novel draws the ruler in an unfavourable light and it abounds with the narration of many unhappy things. Detention of students, Evacuating slums, Forced vasectomy, Police brutality, Retaliatory murders were some of the cruel measures adopted during Emergency. The impact of these draconian measures is focused in A Fine Balance. Mistry proves himself a realist by representing what really was happening around.
\end{abstract}

Key words: Emergency, hope and despair, plight, socio-political issues

\section{Introduction:}

Rohinton Mistry's creations recall the works of Charles Dickens who with his magical writings has the potential of exploring the socio-political issues of the society. Rohinton Mistry, an Indian Parsi writer left India during the Emergency. Since 1975, he has been living in Canada, but he preserves the memories of his homeland green in his mind and leaves the imprints of those fond recollection in his novels. Like most of the postcolonial writers, he delves into the history of the past and lets his readers know the past; and live in the past. Like Salman Rushdie, a British Indian Novelist, Mistry is deeply concerned with history. Mistry portrays India as a place where only rich people can survive. A Fine Balance unravels the misery caused by the political upheavals which took place during Indira Gandhi's regime. 


\section{Literature Review:}

The bitter experiences experienced by the ordinary Indians during the emergency period raised many eyesores and received more opposition from the onlookers.. Mankekar and Kamla Mankekar in their Decline and fall of Indira Gandhi says :In the name of cleaning and beautifying the city, Jhonpoaridwellers were evicted from their homes and dumped on land several miles away and left to fend for themselves. The atrocities committed and brutal force used on the poor people, both rural and urban, in the name of enforcing family planning,in Delhi and all over northern India, could not have been improved upon Idi Amin's land. (34) Hutoxi G. Wadia in "Shades of Indian modernity in the novels of Rohinton Mistry" compares their sad plight with the condition in Nazi's concentration camps during World War II: Their [Om and Ishvar's] shacks were destroyed and later they were picked up along with a hundred other pavement dwellers and beggars and dumped in a 'work camp' not unlike the Nazi concentration camps of the second world war.... The 17 years old boy is forcibly castrated and Ishvar loses both his legs thanks to the unsterilized surgical instruments used for his sterilization operation. (222). As Pratibha Nagpal in "Over the Bridge, wistfully; On Rohinton Mistry's A Fine Balance" remarks: Widowed at the age of twenty-two, Dina Dalal is a lonely figure in the novel, estranged from her parental family and leading a monotonous existence. Her life has been a cyclic pattern for her, which began in her brother's house and after a brief spell of independence and happiness, has ended with Dina Dalal accepting the emotional subjugation of the patriarchal system that her brother Nusswan symbolizes. (49).

\section{Challenging the victory:}

Mistry fishes out the past in his novels. He speaks in details about the regime of Indira Gandhi in his novel A Fine Balance (hereafter it is referred as Balance). During the 1971 Parliamentary election, Indira Gandhi contested from the Rae Bareley constituency and defeated her opponent Raj Narayan by over one lakh votes. Raj Narayan filed a petition challenging Indira Gandhi's success on six grounds, including the procurement of the government servants for election purpose and using the religious symbols of cow and calf.

On June 12, 1975, the Allahabad high court gave the historical verdict which led to the inglorious Emergency. Justice Jagmohan Lal Sinha of Allahabad High court found Indira Gandhi a corrupt politician and invalidated her electoral victory in 1971. He disqualified her for six years and ordered her to pay the cost to Raj Narayan. She was granted a stay for twenty days in order to file an appeal against the verdict in the Supreme Court. She was upset over the judgement and claimed that the parties in the opposition knew the judgement before it was delivered. Since she spoke against the court proceedings, a case leading to a contempt of court was also filed against her in Allahabad High court. Consequently, the opposition parties demanded her resignation.

There were wide protests against Indira Gandhi, processions were conducted, and meetings were held demanding her resignation. In the mean time, on June 23, Indira Gandhi filed an application before the vacation judge, Justice Krishna Iyer for an absolute stay, which 
would allow her to remain in power as a member of Parliament. But his verdict did not satisfy Indira Gandhi since it was a conditional stay. As per the above verdict Indira Gandhi could neither continue as a Member of Parliament nor vote nor draw salary as a member of parliament but could continue as Prime Minister. The people were extremely angry about the verdict and insisted on her resignation. This was a set back to Indira Gandhi. To escape from the existing fiasco, she imposed internal Emergency on June 26, 1975 and it was in effect for eighteen months. She claimed that she did so because the country was on the brink of disaster. After the proclamation of Emergency, orders were issued for the arrest of opposition leaders all over the country. Darbara singh in his Indian Politics 1968-1978 describes the condition:

No sooner had the President signed the proclamation than a large number of arrests of Opposition leaders, all over the country, were made. For Delhi, especially, Lieutenant Governor, asked for three additional armed police battalions. Shri Jayprakash Narayan was arrested from Delhi at 4.00 am., ....(21-22)

During the Emergency period, Indira Gandhi announced the twenty point programme, with the intention of improving the economic and social condition of the people. She patronized her son, Sanjay, "the apple of her eye", to come up in politics. As the son of the Prime Minister, he implemented a five point programme, which included, Family Planning, Tree Plantation, and Abolishment of dowry, literacy and Beautification of slums. Her intention in announcing the Programmes was good. But her officials at the lower level misused power and consequently the Programmes failed. Many young men were forcibly sterilized. In the name of beautification, many people were evacuated and rendered homeless.

Mistry's second novel, Balance is set in India of mid seventies. It depicts the chaotic condition during the Emergency and portrays it from the point of view of its victims.

Germaine Greer, the Australian feminist writer, rejected Balance which was recommended for 1996 Booker prize during a BBC-TV panel discussion. She branded the book as a Canadian book about India. For, she rarely came across with such terrific incidents in Bombay, when she worked as a Lecturer in a Women's College there. She accused Mistry of giving an untrue account of India.

Mistry gives a fitting reply to Greer's criticism in his Family Matters. Vilas, one of the minor characters in Family Matters, comments derisively:

A while back, I read a novel about the Emergency. A big book, full of horrors, real as life. But also full of life, and the laughter and dignity of ordinary people. One hundred per cent honestmade me laugh and cry as I read it. But some reviewers said no, no, things were not that bad. Especially foreign critics. You know how they come here for two weeks and become experts. One poor woman whose name I can't remember made such a hash of it, she had to be a bit pagal, defending Indira, defending the Sanjay sterilization scheme, defending the entire Emergency-you felt sorry for her even though she was a big professor at some big university in England. What to do? People are afraid to accept the truth. As T.S. Eliot wrote, 'Human kind cannot bear very much reality. (Family Matters 202-203) 
The story of Balance has a pinch of politics in it. Though Mistry does not name Indira Gandhi directly, the incidents narrated in the novel perform the verisimilitude representation of her period. Deaths on railway tracks, brutal murders, demolition of slums, death in police custody, atrocities of the landlords, deaths during family planning, lathi charges and students' deaths in the novel remind the readers of the turmoil during the Emergency. In A Fine Balance Mistry has portrayed four main characters who hail from diverse set up. The novel opens with a train journey, in which Maneck, a student meets Ishvar and his nephew Om, the cobblers. They soon come to know that they are heading towards a common destination - Dina's house. Maneck stays in Dina's house as a paying guest. Dina hires Ishvar and Om as her tailors for sewing dresses for Au Revoir Export company run by Mrs. Gupta. They find a house in a slum area. Quite naturally, the slum dwellers Rajaram, the hair collector, and monkey man become their friends.

During Emergency Family Planning was made almost compulsory and the sterilized people were rewarded with gifts. The government sought the help of the officers to hunt down people. Mistry handles this situation quite artistically. While Ishvar and Om apply for a ration card, the officer urges them to do vasectomy. Nearly all the officers are in an unpleasant predicament as they are forced to produce more cases in order to remain secure in their jobs. One of the facilitator's comments:

You see, since the Emergency started, there's a new rule in the department-every officer has to encourage people to get sterilized. If he doesn't fill his quota, no promotion for him. What to do, poor fellow, he is also trapped, no? (Balance 207)

Om is a young man and his uncle Ishvar always dreams of his marriage. The latter wants to see Om, leading a happy married life. But Om is not for marriage and on one occasion he revealed his wish of getting a transistor in exchange of his manhood and Ishvar is shocked. Om explains quite unwittingly, "No, yaar, it's not your manhood they want. The doctor just cuts a tiny little tube inside. You don't even feel it" (Balance 225).

While talking about Indira Gandhi, Mistry's tone gains harshness. He presents her as a corrupt politician, who misused her power to make her position safe. He makes a scathing attack on Indira Gandhi and Sanjay Gandhi. After the declaration of Emergency, there were several protests against Indira Gandhi. But she tried to pose herself as the saviour of the nation. She organized various political meetings and people were forcibly brought from many places to attend the meetings. Mistry describes this situation in Balance. The party workers invite the slum dwellers to attend her rally because, "The Prime Minister's message is that she is your servant, and wants to help you. She wants to hear about things from your own lips" (Balance 300). The slum dwellers react angrily, their tone tinged with sarcasm.

"Yes! Tell her how happy we are! Why do we need to come?"

"If she is our servant, tell her to come here!"

"Ask your men with the cameras to pull some photos of our lovely houses, our healthy children! Show that to the Prime Minister!” (Balance 300) 
It is believed that the poor people are easily led as they are ignorant of their sad plight. When the party workers promise five rupees and free tea, they line up to attend the meeting. In the meantime, Sergeant Kesar threatens the dwellers that if they do not get into the bus within five minutes, they will be arrested for trespassing into the municipal property. Ishvar and Om also decide to attend the meeting to see the "government tamasha" (Balance 6). The people who have gathered to attend the meeting feel difficult to stand under the hot sun. In the beginning when the dignitaries garland Indira Gandhi, it appears funny to them. Later on, she throws the garland into the audience. Om comments: "She looks like she is throwing rubbish at us" (Balance 306). The dignitaries talk in praise of the Emergency and praise her as Mother India. Mistry presents the political hypocrisy of Indira Gandhi quite ironically through the words of the dignitaries on the stage:

... and yet there are people who say she must step down, that her rule is illegal! Who are these people uttering such falsehoods? Brothers and sisters, they are the pampered few, living in big cities and enjoying comforts that you and I cannot even dream about. They do not like the changes the Prime Minister is making because their unfair privileges will be taken away. But it is clear that in the villages, where seventy-five per cent of our people live, there is nothing but complete support for our beloved Prime Minister. (Balance 307)

Indira Gandhi explains that she was forced to impose Emergency to save India from the hands of enemies. It is nothing but a measure to fight the forces of evil and the crooks. She also says that only the smugglers need to be afraid of the Emergency, and not the ordinary people. While she explains the Twenty-point programme, the audience does not bother to listen to her but involve themselves in chatting and playing cards.

As the speech touches its climax, the audience notices a huge hot air balloon and slowly recognizes the person in it. He is none other than Sanjay Gandhi. He throws a few leaflets containing the Prime Minister's picture and the twenty-point programme. On seeing this, one of the dignitaries says through the microphone:

...Mother India sits on stage with us, and the Son of India shines from the sky upon us! The glorious present, here, now, and the golden future, up there, waiting to descend and embrace our lives! What a blessed nation we are! (Balance 310)

Suddenly, the Prime Minister's eighty-foot cut-out begins to fall down in the force of the gale caused by the rotating blade of the helicopter and the people run helter-skelter. Rajaram, the hair collector remarks cynically: "Nobody wants to be caught in the Prime Minister's embrace" (Balance 311). Om retaliates: "But she tries to get on top of everyone" (Balance 311). At the end of the programme, the slum dwellers get neither their snacks nor five rupees as the party workers promised. In turn, they get only four rupees as one rupee each is deducted to meet their bus fare, tea and snacks. Mistry portrays the desolate condition of the slum dwellers so ironically that Balance can even be called a Dark Comedy. 


\section{Beautification and Evacuation:}

During the Emergency, scheme for Beautification of the City was implemented. As a result, thousands of slums were destroyed. Many people lost their homes. The government officials disguised themselves as safety inspectors. They played tricks on the slum dwellers saying that they were going to improve the condition of their houses. As the slum people came out, they saw the bulldozers demolishing their shacks and thereby rendering them homeless.

Ishvar and Om are affected by the City Beautification Scheme. As a part of this scheme, the huts in the slum in which they stayed are bulldozed to grounds.

Navalkar, and Thokaray who collect the rent for these houses, keep quiet, for, they are now in charge of the City Beautification Scheme. Hoping to get shelter again in tailor Navaz' house, Ishvar and Om reach his house. But they receive the shocking news of Navaz' arrest on the ground of smuggling gold from Gulf. The mistake committed by Navaz is that he asked a rich customer for his payment. "With the Emergency, everything is upside-down. Black can be made white, day turned into night. With the right influence and a little cash, sending people to jail is very easy. There's even a new law called MISA, to simplify the whole procedure" (Balance 348).

Many deaths are reported due to the mistakes committed by the doctors during Family Planning operations. Quite naturally, the motivators become the targets of the agitated public. Mistry describes the story of an old man who died after the operation as the wound in his groin became septic. His relatives beat the motivator Rajaram very badly.

Mistry elaborates on the atrocities committed during the Emergency further by narrating Rajaram, the hair collector's sudden conversion to sainthood. The motivators of Family Planning have to hunt maximum number of patients. Rajaram tries hard to find out cases. But he fails to produce the required number. Hence the officers have asked him to leave the job. So he returns to his old profession of barbering. He kills a beggar couple for hair, but at the end, instead of going to jail, he becomes a sanyasi with the assumed name Bal Baba.

The chemist's shop which is the new home of Om and Ishvar poses a threat to them. One day, while they are sleeping outside the shop, they hear the sounds of trucks and jeeps. Soon, they find out that they are in the brim of danger. The policemen under the leadership of Sergeant Kesar, evict the beggars on the road side and they arrest the two tailors in order to fill their required quota. They are clamped into the camp along with the beggars. The beggars in the camp are compelled to work in the irrigation project. In the camp, they become close to Shankar, a beggar, who is already known to them. At last, Shankar's Beggar Master comes to their rescue and frees them by paying Rs.50,000 since they have promised to pay him the amount in installment.

As the house of Om and Ishvar is demolished, they have nowhere to go. So Dina decides to give them shelter. She, at first, is class-conscious and hesitates to mingle with them freely. Maneck slowly befriends Om and Ishvar. In due course, Dina too, gives up her hostile attitude towards them and becomes friendly with them. Thus Dina, Maneck, Ishvar and Om share the 
same house where they face the sorrows and despair of life together without complaining. But for admitting the tailors in her house, Dina faces many kinds of threats from the house owner as Emergency bestows additional power to such owners. He even asks her to vacate the flat claiming that she is using his house for business purpose.

In the meantime, unfortunately, Ishvar and Om meet their old enemy Thakur Dharamsi who is now in a new incarnation. He is in charge of Family Planning in the village, about whom, Ashraf grumbles:

...that demon is too powerful. Since the Emergency began, his reach has extended from his own village to all the way here. He is a big man now in the Congress Party, they say he will become a minister in the next elections-if the government ever decides to have elections. Nowadays, he wants to look respectable, avoids any goonda-giri. When he wants to threaten someone, he doesn't send his own men, he just tells the police. They pick up the poor fellow, give him a beating, then release him. (Balance 602-603)

Mistry points out clearly how Emergency has empowered such mean fellows like Thakur to enjoy excessive power. Those who were in charge of the Family Planning Schemes, compelled the poor people to do vasectomy. By portraying characters like Thakur, Mistry draws, with a touch of realism, the exact picture of the politicians of the period and their cruelty. Thakur Dharamsi threatens the poor people with dire consequences if they refuse to do family planning. On hearing about the atrocities of Thakur, Om bursts out: "Killing that swine would be the most sensible way to end Kaliyug" (Balance 603). Thakur Dharamsi accumulates more and more wealth from the fund allotted to family planning. The government gives orders not to pay the government employees, if they fail to produce two or three cases for sterilization. Dharamsi makes use of this chance and invites the government employees including school teachers, Tax collectors, Block development officers to the clinic and auctions the villagers. The highest bidder gets the cases registered in his quota. Ashraf reflects over the ordinary Indian's anguish: "To listen to the things happening in our lifetime is like drinking venom- it poisons my peace. Every day I pray that this evil cloud over our country will lift, that justice will take care of these misguided people" (Balance 604).

On realizing Takur's beastly nature, Om's heart is filled with an undying hatred for him and spits at him while he passes by his side. But Ishvar and Ashraf are afraid of Thakur and scolds Om for this. Suddenly, while they are conversing, there is a commotion in the market place. The police vandalise the whole market and compel all the people including old men, young boys, housewives, and children to get into the trucks. Ishvar, Om and Ashraf run to hide themselves but the police catch hold of them. While Ashraf protests, he is badly beaten by the police and he dies of police brutality. Ishvar and Om are forcibly taken to the sterilization camp. In the camp, even sixteen year old boys and 60 year old women are sterilized by force. Ishvar exhorts the doctor to leave his nephew $\mathrm{Om}$ as his wedding is going to be solemnized very soon: Doctorji, you are like mother-father to us poor people, your good work keeps us healthy. And I also think nussbandhi is very important for the country. I am never going to marry, Doctorji, please do the operation on me, I will be grateful, but please leave out my nephew, Doctorji, his 
name is Omprakash and his wedding is happening soon, please listen to me, Doctorji, I beg of you. (Balance 619)

But Ishvar's earnest exhortation falls on deaf ears. Om is castrated. Thus Thakur Dharamsy, the in charge of the camp settles his score. Om and Ishvar complain at the police station and at the Family planning centre. But they refuse to register a case: "We are fed up with you ignorant people. How many times to explain? Nussbandhi has nothing to do with castration- why don't you listen to our lectures? Why don't you read the pamphlets we give you?" (Balance 626). Mistry wants to point out that during the Emergency the police were with the influential.

As the doctors have done the surgical operation in poor hygienic condition, the sore in the groin spreads to Ishvar's knee, and hence the doctors amputate Ishvar's legs. He is given a little trolley with small wheels and he practices the wheel chair. Ishvar and Om thus become helpless handicaps. They are not able to do tailoring any more. Eventually, they become beggars.

Ishvar and Om come to the city with great ambition in their mind, but finally they become mere beggars, losing everything in their life. There is no balance between hope and despair, but only despair overwhelms them. After their entire family is ruthlessly murdered by Dharamsi's men, they come to Bombay. But fate chases them wherever they go. They shift their dwelling place to escape from the clutches of the champions of Emergency. They move from Nawaz' house to a slum, then to the railway platform, from there to the verandah of a chemist's shop where they are mistaken for beggars and compelled to be admitted in a Beggars Camp. At last they end up by becoming real beggars.

During the Emergency, the laws were favourable only to the rich. Mistry points out the tendency of the high class people through the characters, the landlord, Thakur Daramsi, Sergeant, and others. He speaks about the hardships undergone by a Parsi woman during the black days of Emergency. Dina's landlord tortures her in several ways. He sends his thugs in order to evacuate her from the flat. Having given her forty-eight hours time, he sends Ibrahim, the rent collector, along with the goondas. They ransack her house. They damage the sewing machines and the new dresses which are ready to be delivered. They attack Maneck for protesting against the damage. Even the police join hands with the goondas. Ibrahim's comment denotes the helplessness of the poor: "These Emergency times are terrible, sister. Money can buy the necessary police order. Justice is sold to the highest bidder" (Balance 503).

To defend her rights, Dina seeks the help of the lawyer Vasantrao Valmik who once met Maneck during a train journey. The lawyer is at once the voice of Mistry. He vehementally criticizes the supreme court's verdict in changing the Prime Minister's guilt into innocence. Mistry, through Valmik, remarks: "The Prime Minister cheats in the election, and the relevant law is promptly modified. Ergo, she is not guilty. We poor mortals have to accept that bygone events are beyond our clutch, while the Prime Minister performs juggling acts with time past" (Balance 651). He finds the poet W.B.Yeats' words relevant to the Emergency and he feels that it is the time for anarchy and commotion. He is dejected and quotes Yeats: “...You know- 
things falling apart, centre not holding, anarchy loosed upon the world, and all that sort of thing" (Balance 656).

Ironically, the Emergency has patronized only crooked fellows. One such mean fellow portrayed is the influential Beggar Master in Balance. Many beggars work under him.He teaches them the art of begging. He extracts money from them. His primal work is to give training to young children. He has invisible links with the higher authorities. He promises Dina that he would save her from her landlord. In Dina's words, “... What a peculiar fellow. And that briefcase chained to his wrist- a slave to money. He looks capable of selling our bones before we're finished with them" (Balance 518).

Emergency has left the Parsi lady Dina to live in dread and despair. Dina wishes to lead an independent life after her husband's death. She wants to maintain her individuality by freeing herself from the clutches of her brother Nusswan. She does not want to accept fate as the only alternative. Rustom's uncle Darab and aunty Shirin encourage her in starting a tailoring business. She strives hard to come up in her life. She hopes that she can maintain her individuality throughout her life but Emergency has frustrated her plans; her tailors turn beggars and she is forced to vacate her house. Thus she loses her confidence and consequently becomes desperate. At last, she finds shelter in Nusswan's house as an unpaid servant maid. Thus Mistry has described how the Emergency has left permanent wounds on the Indian Parsi woman.

Mistry in Balance has tactfully made use of a real incident that occurred in Kanpur in the 1980, in which a family was victimized during the Emergency. Avinash, the President of the Student Union and Chairman of the Hostel Committee comes closer to Maneck. He hails from a poor family in Kanpur. He joins the college with great hopes and expectations. He proudly admits: "I was the first one ever to finish high school in our family. Everyone's relying on me. My three young sisters, too. I must collect money for their dowries, or they won't be able to get married" (Balance 277). During the Emergency, students also get involved themselves in the agitation. Many students face dire consequences for raising their voice against Emergency. They are attracted by the Gandhian principles of Jay Prakash Narayan. Avinash also gets motivated and he becomes a noted student leader for the police. The story of his initiation into politics is facilitated by a very insignificant event. The incident which draws Avinash into the political circle is of less significance. The vegetarian students of the hostel find a piece of meat in their vegetarian gravy of lentils. They register their protest under the leadership of Avinash. Mistry has the following remark about the students:

The students fervently believed their example would inspire universities across the country to undertake radical reforms, which would complement the grass-roots movement of Jay Prakash Narayan that was rousing the nation with a call to return to Gandhian principles. The changes would invigorate all of society, transform it from a corrupt, moribund creature into a healthy organism that would, with its heritage of a rich and ancient civilization, and the wisdom of the Vedas and Upanishads, awaken the world and lead the way towards enlightenment for all humanity. (Balance 283) 
In support of Emergency, there are new groups like Students for Democracy, Students against Fascism, to silence those who criticize or talk ill of Emergency. Professors are also arrested under the Maintenance of Internal Security Act (MISA). Lecturers and professors are compelled to sign in the statements declaring that they are behind the Prime Minister and for Emergency. In the meantime, Avinash disappears from the hostel. Maneck suspects the canteen caterer behind his disappearance. After the proclamation of Emergency, senior students behave very cruelly. They rag the junior students in a brutal manner. Maneck becomes one of their victims. On his way to the toilet, the senior students take him to the workshop, and put him in the working model of a freezer for seven minutes. He defecates in the freezer out of fear. They also sexually harass him. The hostel environment does not permit him to stay there and later on, he shifts his abode to Dina's house.

Maneck cannot meet Avinash for many days. In the meantime, he receives the news about the death of Avinash' from his parents. According to the police, Avinash died while he fell off a fast train. But Avinash' father does not believe the tale concocted by the police:

At last, after such a long time, we saw our son. We saw burns on many shameful parts of his body, and when his mother picked up his hand to press it to her forehead, we could see that his fingernails were gone. So we asked them in the morgue, how can this happen in falling from a train? They said anything can happen. Nobody would help us. (Balance 578-579)

\section{Discussion and Conclusion:}

Avinash' death comes as a shock to Maneck. After ten years, Maneck goes to a Gulf country seeking material prosperity. He returns to India in 1984 to attend the funeral of his father. $\mathrm{He}$ very casually goes through old newspapers. The item in the news reporting the suicide of three sisters arrests his attention. He soon finds out that they are the sisters of Avinash. They did so "to spare their mother and father the shame of three unmarried daughters" (Balance 689). The newspaper carries the interview of Avinash' parents who inform that their son's death was not a natural one because, ".... in view of the political climate during the Emergency, and the fact that their son, Avinash, was active in the Student Union, it would appear to be one more case of wrongful death in police custody" (Balance 689). Grief stricken and frustrated, Maneck calls God "the Bloody Fool” (Balance 690).

Mistry describes Maneck's wretched state :

He saw only that photograph. Three saris gripping those fragile necks...Avinash's three sisters...he used to enjoy feeding them when they were little, they used to bite his fingers in fun. And the poor parents... what sense did the world make? ... Did He have no notion of fair and unfair? Couldn't He read a simple balance sheet. (Balance 690)

The new incarnation of the murderer Rajaram, Dina's sufferings, the plight of Avinash' family and the brutality inflicted on his friends Ishvar and Om facilitated by Emergency have disturbed Maneck. He fails to understand the mystery of life. Hence he commits suicide by throwing himself before a train carrying Avinash' chess in his hands. 
Mistry in Balance focuses his attention on the lives of the four protagonists viz., Ishvar, Om, Dina and Maneck. They succumb to the hardships of Emergency, and to fate and become destitute and desperate. They fail to get a fine balance between hope and despair unlike the murderer Rajaram who achieves a good balance by becoming Bal Baba. Whereas for Dina Dayal, the principal character in Balance, the question of individuality is more crucial. She undergoes lot of sufferings in the patriarchal society and Mistry has presented her as a woman revolting against the deep-seated patriarchal set up. She tries her utmost level to overcome male chauvinism imposed by her brother Nusswan. The condition of Om and Ishvar is pitiable. They migrated to the city with lots of hopes. but the ending is crucial. Balance, highlights how the ordinary citizen in India feel difficulty in balancing his life between hope and despair. Having arrived at the city to continue his studies, Maneck faces depression due to the sad plight of his intimate friends Ishvar and Om. He resorts to the extreme step of committing suicide. Dina Dayal, loses her individuality and becomes a mere servant in her brother's household.. The proclamation of Emergency has marred her self-image Thus, the four innocent people, for no fault of theirs, are subjugated to destiny's vagaries because of Emergency.

\section{Works Cited}

\section{Primary Sources}

Mistry, Rohinton, Such a Long Journey. London: Faber and Faber, 1991.

- - -A Fine Balance. New Delhi: Rupa, 1995.

- - -, Family Matters. London: Faber and Faber, 2002.

\section{Secondary Source}

Biring, Jagroop.S. 2006. Rohinton Mistry' Family Matters: A Critique of Ethnic Discourse. The Quest (1), 54-61.

Kulke, Eckehard. 1974. The Parsees in India: A Minority as Agent of Social Change. Delhi: Vikas Publishing.

Pathak, R.S.(eds.). 2001. Power, Politics and Politicians in the PaRoutledgersi Novels. Parsi Fiction. Novy Kapadi, Jaydipsinh Dodiya and R.k.Dhawan. New Delhi: Prestige Books.

Singh, Darbara. Indian Politics 1968-1978. Delhi: Sundeep Prakashan, 1978.

Tyson, Lois (ed). 2006. Critical Theory Today: A User Friendly Guide. New York: .

\section{Acknowledgement:}

I would like to express my gratitude to my supervisor, Dr. S. Prabahar, who guided me throughout this project. I would also like to thank my friends and family who supported me and offered deep insight into the study. 